\title{
Sciendo
}

Administration, vol. 67, no. 1 (2019), pp. 45-50

doi: 10.2478/admin-2019-0006

\section{Education, 2018}

\author{
Joanna O'Riordan \\ Institute of Public Administration, Ireland
}

In October it was announced that Joe McHugh, TD, had been appointed Minister for Education and Skills, replacing Richard Bruton, TD, as part of a series of ministerial changes made in the wake of the resignation of Denis Naughten, TD.

\section{Industrial relations and 'equal pay'}

In the 2017 Public Service Stability Agreement (PSSA), the successor to the Lansdowne Road Agreement, the government committed to examining the issue of 'new entrants', those recruited since the 2011 pay-scale changes.

As part of the austerity measures of 2011, the pay scale of new recruits to the public service was reduced by 10 per cent. Within the Education sector, allowances - for example, for qualifications - were also significantly reduced, resulting in an even greater disparity between pre- and post-2011 recruited colleagues. This issue is referred to as 'equal pay', the implication being that there should be 'equal pay for equal work'.

Following negotiations, in September the government put forward proposals providing for new entrants to skip certain incremental points on their pay scale so that they would ultimately catch up with colleagues. However, the lower starting rates remained and allowances were not reinstated.

According to Miley (2018a), this left the three teachers' unions the Teachers' Union of Ireland (TUI), the Association of Secondary 
Teachers, Ireland (ASTI) and the Irish National Teachers' Organisation (INTO) - with a dilemma when balloting their members on the deal. Should they recommend to members that they accept the proposals, bank whatever gains were achieved and continue their campaign to achieve full equality? Or should they recommend rejection because the offer did not represent full parity? The issue was further complicated by the fact that the government would regard any trade union engaging in industrial action as repudiating the terms of the PSSA. This would result - for all members, not just new entrants in a suspension of the payment of increments to teachers and also the pay restoration increases provided for in the PSSA. In the end the three unions put the proposals to ballots of their members in autumn without any recommendation.

The TUI accepted the proposals by 53 to 47 per cent, while the ASTI and the INTO rejected the proposals, both also by a margin of 53 to 47 per cent (Miley, 2018b). As of the end of the year, all three unions were in talks in respect of possible industrial action. It is anticipated that ballots on strike action will take place early in 2019 .

\section{Teacher recruitment and retention}

Throughout the year there was a growing indication that there was a shortage of qualified teachers in Ireland and that the problem is likely to worsen due to a significant spike in student numbers over the next six years. Latest forecasts indicate that the number of students at second level will increase by 40,000 by 2024 . According to the TUI (O'Brien, 2018a), this requires an additional 2,000 teachers to be appointed over the period in order to maintain pupil-teacher ratios, which are already among the highest in the OECD.

According to the OECD's Education at a Glance 2018, published in September, the average primary school class across the OECD in 2016 comprised twenty-one students. Ireland, with an average of twentyfive students was ranked fifth-highest in the thirty-six country OECD. Only the UK, Japan, Israel and Chile had slightly larger classes. At second level Ireland has the ninth-highest pupil-teacher ratio.

At second level, according to the TUI (O'Brien, 2018a), there was a 50 per cent decline in the numbers applying for postgraduate teacher education courses between 2011 and 2018. It is suggested that this is partly because of the abolition of the old Higher Diploma in Education and its replacement by the two-year Masters in Professional Education, making it a more costly and longer process to qualify as a 
teacher. The reduced pay scales further impact on demand for teacher-training courses and also, notwithstanding the shortage of teachers, difficulties experienced by many graduates in obtaining permanent, full-time posts.

\section{The Education (Admission to Schools) Act, 2018}

The Education (Admission to School) Act, 2018, was signed into law in July. The aspect of the legislation to receive most attention was Section 11, the provision amending the Equal Status Act, 2000, to remove the existing provision permitting schools to use religion as a selection criteria in school admissions where they are oversubscribed - the so-called 'baptism barrier'. The legislation only applies to Catholic schools as minority faith schools are given an exemption which enables them to continue to give priority to children of the same or a similar religion.

Other aspects of the legislation to be commenced include an explicit prohibition on public schools charging fees or seeking payment for admission to the school. Voluntary contributions will continue to be allowed. Also, the legislation affords the Minister for Education with power, after a process of consultation, to compel a school to make additional provision for the education of children with special needs; for example, to open a special class.

The commencement of the Act in October left many schools facing considerable administrative difficulties as they had already begun processing applications for admissions in September 2019 (O'Brien, $2018 \mathrm{~b}$ ). The lack of consultation with school boards of management and relevant patrons in respect of schools changing their admissions policy was also highlighted.

\section{Carter review}

In September Mr Justice Richard Humphreys judged that the State Examinations Commission was highly unfair in processing the appeal of Wexford student Rebecca Carter, that the current correction process 'is manifestly unfit for purpose' and that the situation should not be allowed to continue in future years (Mooney, 2018).

The judgement followed a case taken by Ms Carter to be allowed enter veterinary medicine in UCD in autumn 2018 after a recheck of her Leaving Certificate Business exam showed that her points had been wrongly calculated, and consequently that she had obtained 
more than the number of CAO points required for the course. Decisions from rechecks of Leaving Certificate exams usually only become available in mid October, after the universities and colleges have closed admissions, resulting in students being required to wait a year to take up places on higher-preference courses. Ms Carter, who had viewed her script, was aware that her marks for the different sections of the exam had been incorrectly tallied, and took the case to seek to accelerate the process. Approximately 5,000 students annually appeal their results. According to some education sources (O'Brien, 2018c), the implications for state exams are significant as it will require rechecks to be carried out over a period of about a fortnight at a time when teachers have returned to school after summer holidays

\section{Gender equality action plan for higher education institutions}

In November Taoiseach Leo Varadkar, TD, and the Minister of State with Special Responsibility for Higher Education, Mary Mitchell O'Connor, TD, launched the Gender Action Plan: Accelerating Gender Equality in Irish Higher Education Institutions. Following recommendations made by the Higher Education Authority, a gender equality taskforce was established in 2016 to identify factors that would help women achieve gender equality in higher education institutions. Data collected by the taskforce revealed that 51 per cent of lecturing staff at third level were women but that only 24 per cent of professors were female. The government has set a target of 40 per cent female professors by 2024 and have provided funding for forty-five womenonly posts to help move towards this target.

\section{WBS building issues}

In December it was announced that the Department of Education will sue Tyrone-based Western Building Systems (WBS). A number of schools built by the contractor were at the centre of inspections and some closures over concerns about structural issues throughout the year. WBS have built forty-two schools around the country in the past fourteen years. The case will proceed early in the new year.

\section{Kildare and Wicklow ETB}

In September Minister Bruton published the final report of the 'Investigation into Certain Matters in Kildare and Wicklow Education 
and Training Board', carried out by Dr Richard Thorn. The report makes twenty-three findings and fifteen recommendations to be implemented by the education and training board (ETB). The report also indicates that the investigator referred a matter relating to a particular tendering process to the Garda National Economic Crime Bureau. All other ETBs were asked by the minister to examine the report and to verify their practices in relation to governance and oversight of procurement and conflicts of interest, and to confirm whether any similar issues arise in respect of their organisations.

\section{The Technological Universities Act}

The Technological Universities Bill - which will unite the institutes of technology into four technological universities - was passed into law in March. First proposed in 2015, the bill experienced several delays. The legislation had been sought by the sector to improve their international standing, to attract more foreign students and investment, and to diversify the education they were providing.

The process of the mergers is now set to commence with Dublin Institute of Technology, Institute of Technology Blanchardstown and Tallaght Institute of Technology due to come together under the moniker of TU Dublin. Their amalgamation will lead to fewer duplicate courses, more financial resources and a technological university qualification for all of its students.

Elsewhere across the country, Waterford Institute of Technology and the Institute of Technology Carlow will unite to form the Technological University for the South East. The Connacht Ulster Alliance will be created when the Institute of Technology Sligo, Letterkenny Institute of Technology and the Galway Mayo Institute of Technology are merged under the bill. The Munster Technological University will be formed by the merger of Cork Institute of Technology and Institute of Technology Tralee.

\section{John Coolahan}

The death occurred in June of John Coolahan, emeritus professor of education at NUI Maynooth. Coolahan was one of the most influential shapers of policy in respect of education in Ireland. In 2017 the Institute of Public Administration published John's history of education in Ireland, Towards the Era of Lifelong Learning: A History of Irish Education 1800-2016. 


\section{References}

Miley, I. (2018a). As primary teachers reject pay equality proposals, is there a real threat of strikes in schools? Retrieved from https:/www.rte.ie/news/analysisand-comment/2018/1031/1007858-teachers-into/ [18 January 2019].

Miley, I. (2018b). ASTI votes to reject government pay proposals. Retrieved from https://www.rte.ie/news/2018/1129/1014031-asti_ballot/ [18 January 2019].

Mooney, B. (2018). Leaving Cert appeals process must enter the 21st century. Retrieved from https://www.irishtimes.com/opinion/leaving-cert-appealsprocess-must-enter-the-21st-century-1.3643644 [18 January 2019].

O'Brien, C. (2018a, November 15). Principals warn teacher shortage will worsen due to spike in student numbers. The Irish Times.

O'Brien, C. (2018b, October 3). 'Baptism barrier' to be removed from primary schools next year. The Irish Times.

O'Brien, C. (2018c, September 27). Leaving Cert student's victory could mean 'chaos' for State exams. The Irish Times. 